\title{
Modelling strategies for the reduction of fat dormice in northern Italian hazel groves.
}

\author{
Giovanni Scire' \\ Department of Political Sciences and International Relations \\ Università degli Studi di Palermo \\ Palermo, Italy \\ Email: giovanni.scire01@unipa.it
}

Biographical notes: Giovanni Scire' is a Ph.D. candidate in "Model Based Public Planning, Policy Design and Management" at Università degli Studi di Palermo (Italy).

During his Ph.D., he was a visiting student at University of Bergen (Norway) and at Radboud University, Nijmegen (Netherlands). Previously he studied Economics and Management at Alma Mater Studiorum - Università di Bologna and at Università degli Studi di Palermo. His field of research regards Public Governance, Healthcare and Agriculture.

\begin{abstract}
The production of hazelnuts represents an important resource for several Italian rural areas. Sicily and Piedmont, two of the most important producers of hazelnuts, are affected by the presence of the dormouse (Glis glis), that has considerably severely harmed the production of hazelnuts. This study aims to analyse the issue in the Province of Cuneo in Piedmont and to evaluate the sustainability of the policies implemented by using the System Dynamics (SD) methodology. An SD predator-prey microworld was built to reproduce the main relevant cause and effect relationships between the development of the dormouse population and local hazelnut production. The results of the SD microworld simulation show the effects of reduction policies on hazelnut production over time. The findings and further research recommendations are briefly reported in the conclusion section.
\end{abstract}

JEL code: Q10, Q18, Q28

KEYWORDS: MODEL FOREST, SYSTEMS ANALYSIS, SYSTEMS DYNAMICS, FAT DORMOUSE, EDIBLE DORMOUSE, HAZELNUTS, DYNAMIC SUSTAINABILITY, AGRICULTURE, PREDATOR-PREY MICROWORLD, DYNAMIC MODEL, STOCK AND FLOW DIAGRAM, CASUAL LOOP DIAGRAMS.

\section{Introduction}

Recently, Italian hazelnut production suffered a loss with serious socio-economic repercussions in some areas, due to the presence of the fat dormouse, Glis glis that represents the largest member of the dormouse (Gliridae) family and has several specific characteristics. A feature distinctive to dormice, hibernation in Glis glis can last up to 7- 
8 months. Before hibernation, dormice accumulate large quantities of body fat by feeding on the most nutritious food sources available in autumn (Juškaitis, 2015, p. 155). Preliminary surveys conducted in the province of Cuneo have found that hazel trees are easily accessible to the rodents, which bring direct damage by consuming hazelnuts (Cimini et al., 2016). In Sicily, local authorities have started to monitor the presence of this animal, as some farmers have already reported a loss of $70 \%$ of their hazelnut crop. The damage caused by the rodents is easy to verify because the shell of the nut is characterized by an abnormal circular cut.

This problem originated in the mid- $20^{\text {th }}$ century, when, in several Italian rural areas, human activity: urbanization, hunting, pollution, and so on, caused a reduction in (in some cases even the extinction of) several predators, such as wolves, eagle owls, and others. This led to the formation of new equilibria, as, for example, in our case, a proliferation of dormice in Sicily and Piedmont.

In the Province of Cuneo in Piedmont, after seeing a drastic loss of production due to the presence of the rodents, local authorities have started to monitor the problem and started collecting data. Even though they have reduced the loss over time (Fig. 1), there is uncertainty over the sustainability of the policies implemented (ISPRA, 2016). 
Figure 1 Hazelnut dynamics data from a public survey
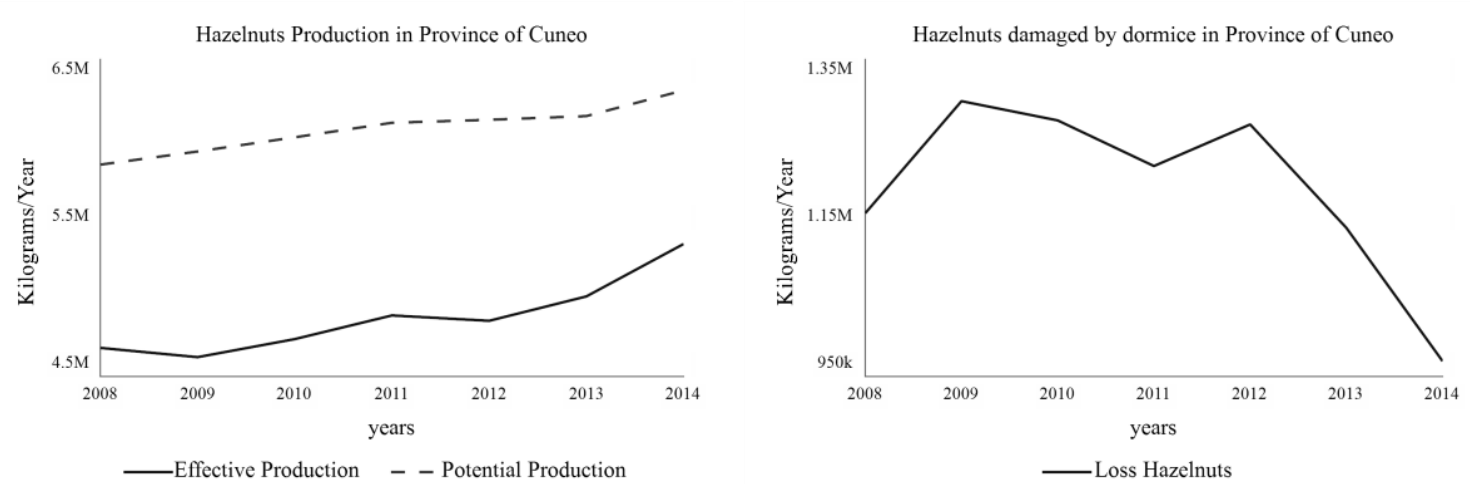

Source: (ISPRA 2015)

In Cuneo, in the mid-70s, the slopes of the areas most affected by the phenomenon (Valli Bormida, Belbo and Alta Langa's Area) were intensively cultivated with cereal crops, meadows and pastures; there were not many hazels. Later, with the gradual depopulation of the hilly areas, the land was gradually abandoned, allowing for the recovery of the forest and its undergrowth, which, together with the now reduced consistency of human presence, have been the ideal habitat for the proliferation of wild animals and species introduced to promote the practice of hunting (primarily wild boars and roe deer) (ISPRA, 2016, p. 1). Since 1990, farmers have cultivated hazels on previously idle land or through the elimination of wooded areas. The development of hazels near the wooded areas has allowed the fat dormice in the woods to feast on hazelnuts, one of their favourite foods (ISPRA, 2016: 1). Dormice are nocturnal rodents and usually live in trees. Their fertility rate can reach 11 offspring per year (Kryštufek, 2010), particularly in the presence of sufficient seed abundance, which acts as an environmental signal to which dormice adjust their reproduction (Lebl et al., 2010).

Since 2008, local public authorities have started to monitor the presence of the dormouse in Cuneo. Although the damage caused by the rodent has decreased, the policy makers are researching new possible solutions.

Hazelnuts and dormice are just two actors in an ecosystem. An ecosystem can be considered a set of plants, animals, fungi and microorganisms that live in biological communities and which interact with each other, the physical and chemical environment, adjacent ecosystems, the water cycle and the atmosphere (Odum, 1989).

The interactions among species in a food web and their relations to water flow and biogeochemical cycling are complex and nonlinear, and contain lags and discontinuities, thresholds and limits (Folke, 2007, p. 30).

Although the environmental conditions vary considerably between the various Italian regions, some characteristics and relationships are the same or strongly similar. Therefore, because no policy has yet been implemented in some regions due to legislative constraints or for lack of data, this study can be a support tool for the formulation of any new policies, taking the case of the Province of Cuneo as an example due to its inherent dynamic complexity.

\section{Material and Methods}

Ecosystems are complex, self-organizing systems nested across temporal and spatial scales (Levin, 1992). The successful management of ecosystems is essential for environmental sustainability (Sonak, 2013, p. 99), defined 
as the maintenance of important environmental functions and hence the maintenance of the capacity of the capital stock to provide those functions (Ekins et al., 2003). Environmental functions in this context can then be defined as the provision by ecosystem of goods and services that satisfy human needs (Sonak, 2013, p. 99).

As agricultural systems shape the very assets on which they rely for inputs, a vital feedback loop occurs from outcomes to inputs (Worster, 1994). Thus, sustainable agricultural systems tend to have a positive effect on natural, social and human capital, while unsustainable ones feedback to deplete these assets, leaving fewer for future generations (Pretty, 2007). Martin et al. (2007) state that natural resource management in complex, adaptive socioecosystems requires a mix of good practice, policy, science and intuition. In this context, an SD approach can facilitate the decision-making process regarding the planning and control of farms, food processing plants and local public authorities (Thompson et al., 2007, Škraba, 2008; Bianchi, 2016).

Chan and Huang (2004) argue that systems thinking and an integrated approach can be appropriate for dealing with the sustainability of local development. The decision-making process regarding the planning of local development also implies the need to identify trade-offs over time (i.e., between the short and long run) and across space (i.e., between one sub-system and another), in relation to alternative policies (Bianchi, 2016, p. 4).

Complex systems are typically characterized by interconnected and interdependent elements and dynamic feedback processes. SD represents a useful methodology to understand the structure and dynamics of complex systems as stated by several scholars (Forrester, 1969; Sterman, 2000; Ford, 2009; Bianchi, 2016). Forrester (1969) developed the SD methodology in the early 1960s with the purpose of studying and managing complex phenomena.

This methodology is also a rigorous modelling method that enables us to build formal computer simulations of complex systems and use them to design more effective policies into the organizations. Indeed, it offers the possibility of creating a safe and controlled laboratory environment, in which it is possible to simulate various policies without creating any damage in the real context. This can support planning and control systems by helping to identify the best strategy; moreover, it can represent an instrument of learning and engagement.

Bianchi (2016) argues that dynamic complexity should be distinguished from combinatorial (or static) complexity. The latter is associated with a high number of variables and multiple relationships, where both relationships and variables tend to remain stable over time. The former is, instead, associated with unpredictability in such interconnections, because of delays, nonlinearities and multiple feedback loops, whose dominance affects the system's behaviour (Senge, 1990; Morecroft, 1998; Sterman, 1994). To study the structure and behaviour of a complex system, it is necessary to engage in an iterative process of developing and refining SD models.

Through SD Methodology, a system can be represented with a Casual Loop Diagram (CLD) or with a Stock \& Flow Diagram (SFD). CLDs are simply maps showing the casual links among variables with arrows from a cause to an effect (Sterman, 2000, p. 102). CLDs are characterised by the presence of reinforcing loops and balancing 
loops ${ }^{1}$. While CLDs help to understand the dynamics of the system from a qualitative perspective, SFDs are a way to reproduce a system from a quantitative perspective ${ }^{2}$.

The model was developed from two different information sources: interviews with experts in the agricultural sector and literature searches. Although the model has some similarities with the Lotka Volterra Models, usually called Prey Predator Models (Wangersky, 1978), there have been no studies on the dynamics between hazel groves and dormice. One of the peculiarities of the population of dormice is its non-linear fertility rate that depends on the availability of food. While, in other models, the fertility rate for each animal remains constant, in this case it will adapt to the needs of the ecosystem, maintaining a balance with the territory.

A synthetic CLD of the issue of the production of hazelnuts in Cuneo, is shown in Figure2, where it is possible to detect the main loops; the dashed lines show the introduction of a policy to increase the gross production, by planting new trees to satisfy market demand. In this case, the growth of the net production will be counteracted by the balancing loops 1 and $2^{3}$. The dotted lines show two different macro-strategies: protecting trees and placing traps to catch dormice. By protecting trees, the population of dormice will reach a new equilibrium (based on the balancing loops) that will be defined by the level of available food. By placing traps to catch dormice, there will be a counter-intuitive phenomenon caused by dynamic complexity. While, in the short run, there will be a reduction in the loss of nuts, caused by the reduction of the population of dormice, in the long run the balancing loops will counteract this strategy. Furthermore, it will be necessary to place more and more traps due to the exponential growth of the population of dormice due to the reinforcing loop.

\footnotetext{
${ }^{1}$ While a reinforcing loop is a loop, where the variables reinforce each other leading to increased growth or decline; a balancing loop is a loop where variables counteract (negative feedback) thus creating a balanced state (Ghosh, 2017, pp.275-277).

${ }^{2}$ Stock-and-flow models use four main kinds of variables, i.e.: (1) stocks, (2) flows; (3) inputs, and (4) auxiliaries (Bianchi, 2016, p. 24).

${ }^{3}$ An increase in available food will lead to an increase in the dormice population that will reduce the net production of hazelnuts.
} 
Figure 2 The causal loop diagram of hazelnut production management in the Province of Cuneo

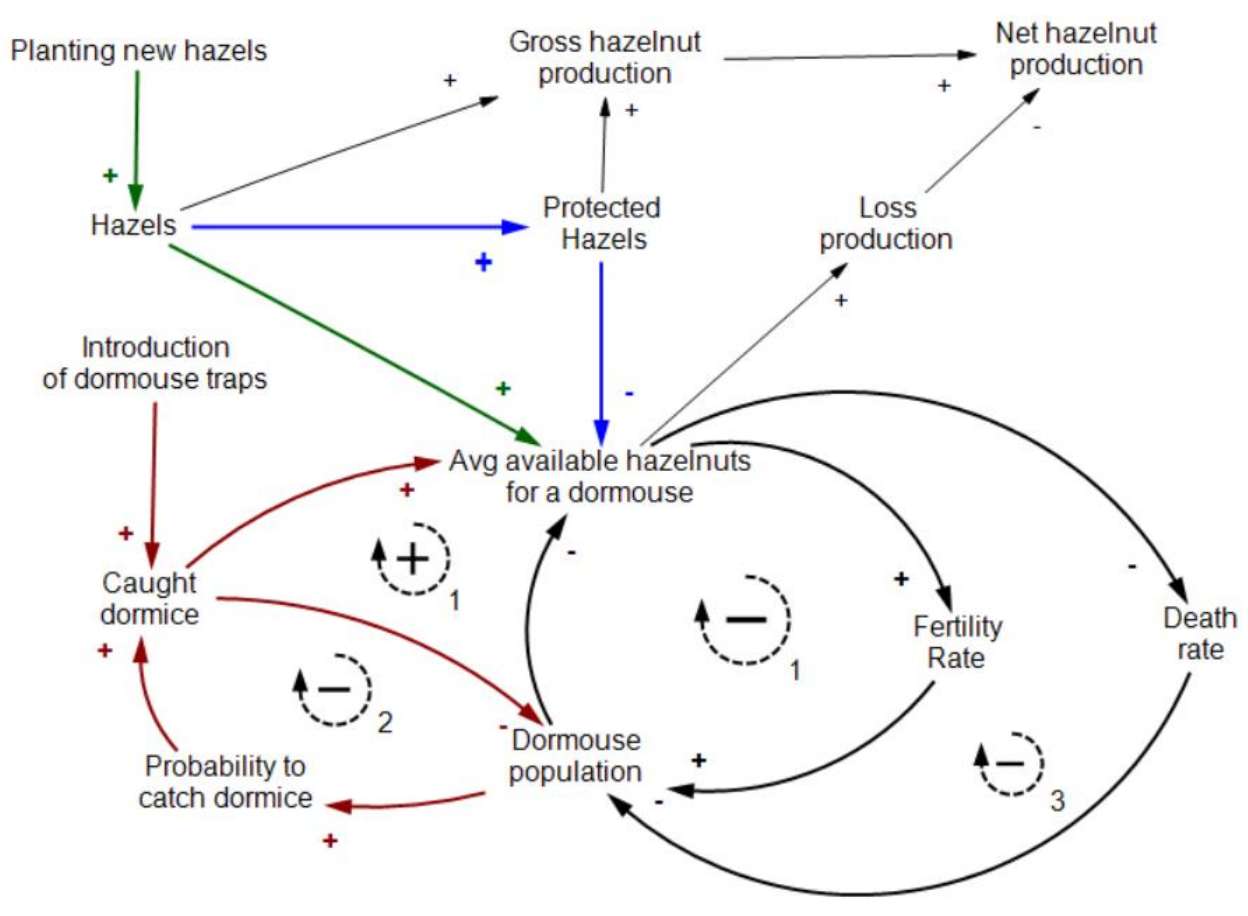

While CLDs represent a purely qualitative model, SFDs allow the quantification of the relationships between the variables. Although it is sometimes possible to get the impression of having purely quantitative models, in this case, the presence of soft variables steers the analysis to have a more qualitative approach, identifying the dynamics of the system and the dominant loops.

Figure 3 is an SFD that includes two interactive subsystems, describing some homogeneous characteristics and simple relations of the main system: Dormice and Hazelnuts. The dynamics of the cultivation of hazelnuts have been analysed using 72 variables, organized in two interdependent subsystems (Hazelnuts and Dormice). Hazels are represented as a stock, while hazelnuts as an auxiliary. Although hazelnuts and hazels should be susceptible to attack by several predators; this model considers only the dormouse as a predator. The system is dominated by several balancing loops because the ecosystem will always try to reach new equilibria, after some exogenous shocks.

Figure 3 shows the Hazelnuts Subsystem of the SFD, while Table 1 shows the variables used and their units of measurement. 
Figure 3 Hazelnut Subsystem

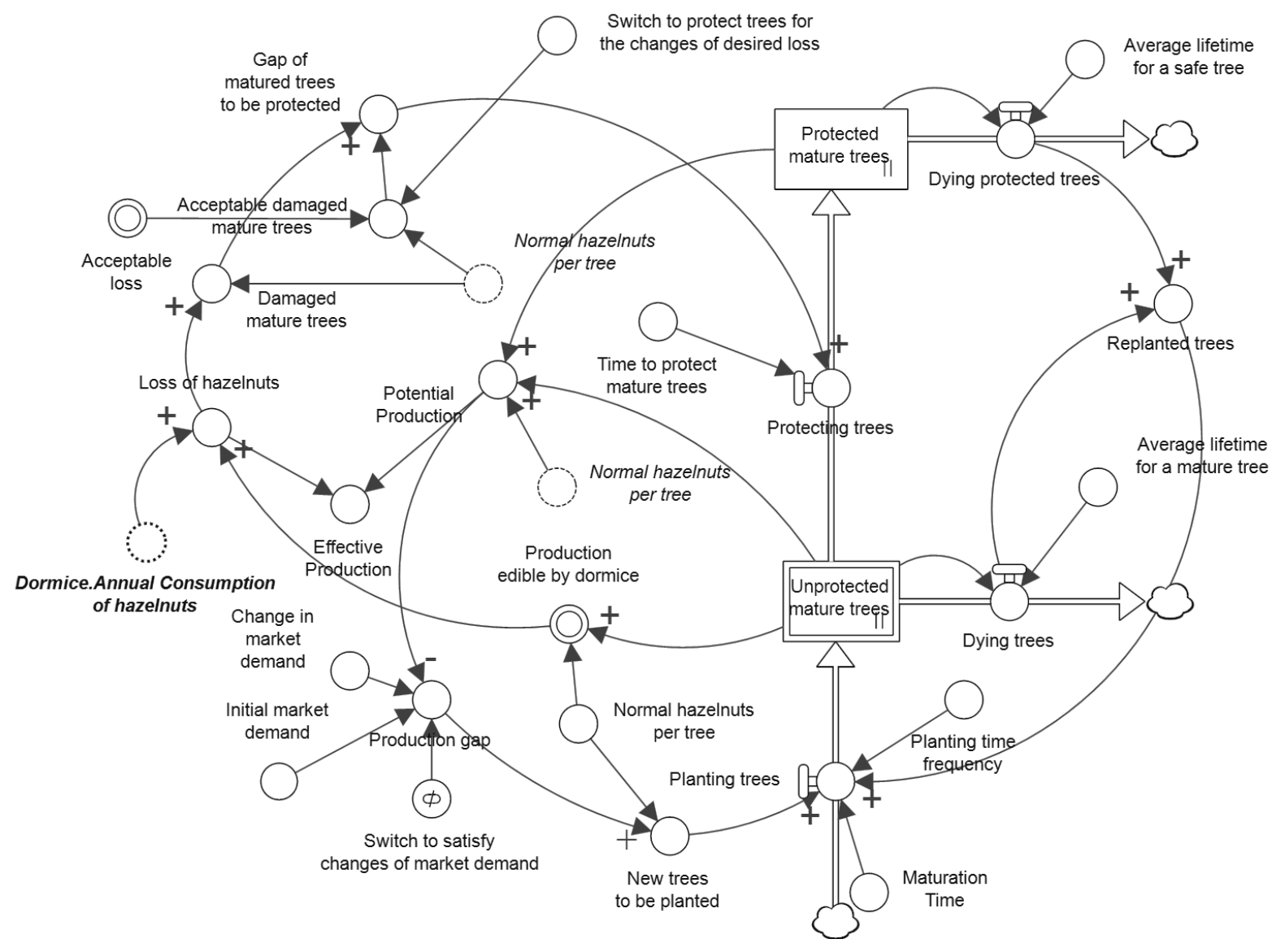


Table 1. List of Variables of the hazelnut subsystem of the SFD

\begin{tabular}{|c|c|c|}
\hline Variable Name & Unit of Measure & General information and assumptions \\
\hline $\begin{array}{l}\text { Desired Acceptable } \\
\text { damaged mature trees }\end{array}$ & 'Number of trees' & $\begin{array}{l}\text { Number of trees damaged by the dormice that can be } \\
\text { accepted by the farmers. }\end{array}$ \\
\hline $\begin{array}{l}\text { Desired Acceptable } \\
\text { loss }\end{array}$ & 'Kilograms'/'Years' & $\begin{array}{l}\text { This variable defines the annual loss of hazelnuts that can be } \\
\text { accepted by the farmers. The model assumes that there is an } \\
\text { initial accepted loss and then this value starts to fall over } \\
\text { time, according to the qualitative information obtained by a } \\
\text { local report of a local public authority (ISPRA, 2015). }\end{array}$ \\
\hline $\begin{array}{l}\text { Average lifetime of a } \\
\text { mature tree }\end{array}$ & 'Years' & A life cycle of 70 years is assumed \\
\hline $\begin{array}{l}\text { Average lifetime of a } \\
\text { safe tree }\end{array}$ & 'Years' & $\begin{array}{l}\text { A life cycle of } 67.5 \text { is assumed, assuming that securing a } \\
\text { tree takes } 2.5 \text { years }\end{array}$ \\
\hline $\begin{array}{l}\text { Change in market } \\
\text { demand }\end{array}$ & 'Kilograms'/’Years' & $\begin{array}{l}\text { Exogenous data that replicate the flow of market demand } \\
\text { data }\end{array}$ \\
\hline $\begin{array}{l}\text { Damaged mature } \\
\text { trees }\end{array}$ & 'Number of trees' & Number of trees damaged by the dormice \\
\hline $\begin{array}{l}\text { Dormice's annual } \\
\text { consumption of } \\
\text { hazelnuts }\end{array}$ & 'Kilograms'/'Years' & $\begin{array}{l}\text { This data reproduces the annual hazelnut consumption of the } \\
\text { dormice }\end{array}$ \\
\hline $\begin{array}{l}\text { Dying Protecting } \\
\text { Trees }\end{array}$ & $\begin{array}{l}\text { 'Number of } \\
\text { trees'/'Years' }\end{array}$ & Number of protected trees that are ending their life cycle \\
\hline Dying Trees & $\begin{array}{l}\text { 'Number of } \\
\text { trees'/'Years' }\end{array}$ & The number of trees that are ending their life cycle \\
\hline Effective production & 'Kilograms'/'Years' & $\begin{array}{l}\text { Net production defined by subtracting dormouse } \\
\text { consumption from gross production }\end{array}$ \\
\hline $\begin{array}{l}\text { Gap of mature trees } \\
\text { to be protected }\end{array}$ & 'Kilograms'/'Years' & $\begin{array}{l}\text { Number of trees to be protected. This value depends on the } \\
\text { strategy of the policy makers. }\end{array}$ \\
\hline Production gap & 'Kilograms'/'Years' & Shortfall in production compared to demand \\
\hline Loss of Hazelnuts & 'Kilograms'/'Years' & $\begin{array}{l}\text { Minimum level between the annual maximum consumption } \\
\text { of the dormice and total production. }\end{array}$ \\
\hline $\begin{array}{l}\text { Initial market } \\
\text { demand }\end{array}$ & 'Kilograms'/'Years' & Exogeneous data collected by ISPRA (2016) \\
\hline Maturation Time & 'Years' & $\begin{array}{l}\text { It is assumed a that the mature trees have a constant } \\
\text { production beyond their maturation age and start producing } \\
\text { hazelnuts } 3 \text { years after planting. }\end{array}$ \\
\hline $\begin{array}{l}\text { New trees to be } \\
\text { planted }\end{array}$ & 'Number of trees' & $\begin{array}{l}\text { New trees to be planted will be defined by dividing the } \\
\text { production gap by normal hazelnuts per tree. }\end{array}$ \\
\hline
\end{tabular}




\begin{tabular}{|c|c|c|}
\hline $\begin{array}{l}\text { Normal hazelnuts per } \\
\text { tree }\end{array}$ & $\begin{array}{l}\text { 'Kilograms'/'Number } \\
\text { of trees'/'Years' }\end{array}$ & $\begin{array}{l}\text { It is assumed that every tree has a normal hazelnut } \\
\text { production of } 5 \text { kilograms per year }\end{array}$ \\
\hline $\begin{array}{l}\text { Planting time } \\
\text { frequency }\end{array}$ & 1/'Years' & $\begin{array}{l}\text { It is assumed that there is only one time per year to plant } \\
\text { new trees }\end{array}$ \\
\hline Planting Trees & $\begin{array}{l}\text { 'Number of } \\
\text { trees'/'Years' }\end{array}$ & $\begin{array}{l}\text { It is assumed that the farmers plant trees according to their } \\
\text { market expectations }\end{array}$ \\
\hline Potential production & 'Kilograms'/'Years' & $\begin{array}{l}\text { This reflects the gross production, without considering any } \\
\text { consumption by the dormice. }\end{array}$ \\
\hline $\begin{array}{l}\text { Production edible by } \\
\text { dormice }\end{array}$ & 'Kilograms'/'Years' & $\begin{array}{l}\text { This value represents the supply of hazelnuts that can be } \\
\text { eaten by the dormice. }\end{array}$ \\
\hline $\begin{array}{l}\text { Protected Mature } \\
\text { Trees }\end{array}$ & 'Number of trees' & The number of trees that have been protected by the farmers \\
\hline Protecting Trees & $\begin{array}{l}\text { 'Number of } \\
\text { trees'/'Years' }\end{array}$ & $\begin{array}{l}\text { This is a policy lever and it depends on the goal of the policy } \\
\text { makers. It is a flow that define the number of trees that are } \\
\text { going to be protected. }\end{array}$ \\
\hline Replanted trees & $\begin{array}{l}\text { 'Number of } \\
\text { trees'/'Years' }\end{array}$ & $\begin{array}{l}\text { In conditions of equilibrium, the farmers will plant the same } \\
\text { amount as the total of dead trees. }\end{array}$ \\
\hline $\begin{array}{l}\text { Switch to protect } \\
\text { trees due to changes } \\
\text { in acceptable loss }\end{array}$ & $\begin{array}{l}\text { Dummy value }(0,1)- \\
\text { unitless }\end{array}$ & This is a policy lever to start the process to protect trees. \\
\hline $\begin{array}{l}\text { Switch to satisfy } \\
\text { changes in market } \\
\text { demand }\end{array}$ & $\begin{array}{l}\text { Dummy value }(0,1) \text { - } \\
\text { unitless }\end{array}$ & $\begin{array}{l}\text { This is a policy lever to increase the gross production, by } \\
\text { planting new trees to satisfy market demand }\end{array}$ \\
\hline $\begin{array}{l}\text { Time to protect } \\
\text { mature trees }\end{array}$ & 'Years' & $\begin{array}{l}\text { It is assumed that trees are protected for an average period of } \\
\text { two years, even if it is plausible to consider a longer period } \\
\text { for the implementation of the protection of the trees (in the } \\
\text { short term, there is not much evidence in previous studies). }\end{array}$ \\
\hline $\begin{array}{l}\text { Unprotected mature } \\
\text { trees }\end{array}$ & Number of Trees & $\begin{array}{l}\text { It is assumed that, at beginning, no tree was protected by any } \\
\text { device (safety nets, ultrasounds, pruning, etc.) These trees } \\
\text { represent the susceptible trees that produce hazelnuts, edible } \\
\text { by dormice. }\end{array}$ \\
\hline
\end{tabular}


The previous subsystem shows that an increase in dormice reduces the effective production, but how do hazelnuts affect the dormice? In Figure 4, it is possible to verify these interactions; moreover, the dotted variables ('Hazelnuts.desired loss', 'Hazelnuts.Unprotected Mature Trees' and 'Hazelnuts.Production edible by dormice’1) are inputs taken from the hazelnut subsystem. Table 2 shows the variables of the dormouse subsystem and the relevant information and assumptions.

\footnotetext{
${ }^{1}$ While 'Hazelnuts.Unprotected Mature Trees' and 'Hazelnuts.Production edible by dormice' are endogenous variables, 'Hazelnuts.desired loss' is considered as an exogenous variable of the hazelnut subsystem.
} 
Figure 4 Dormouse Subsystem

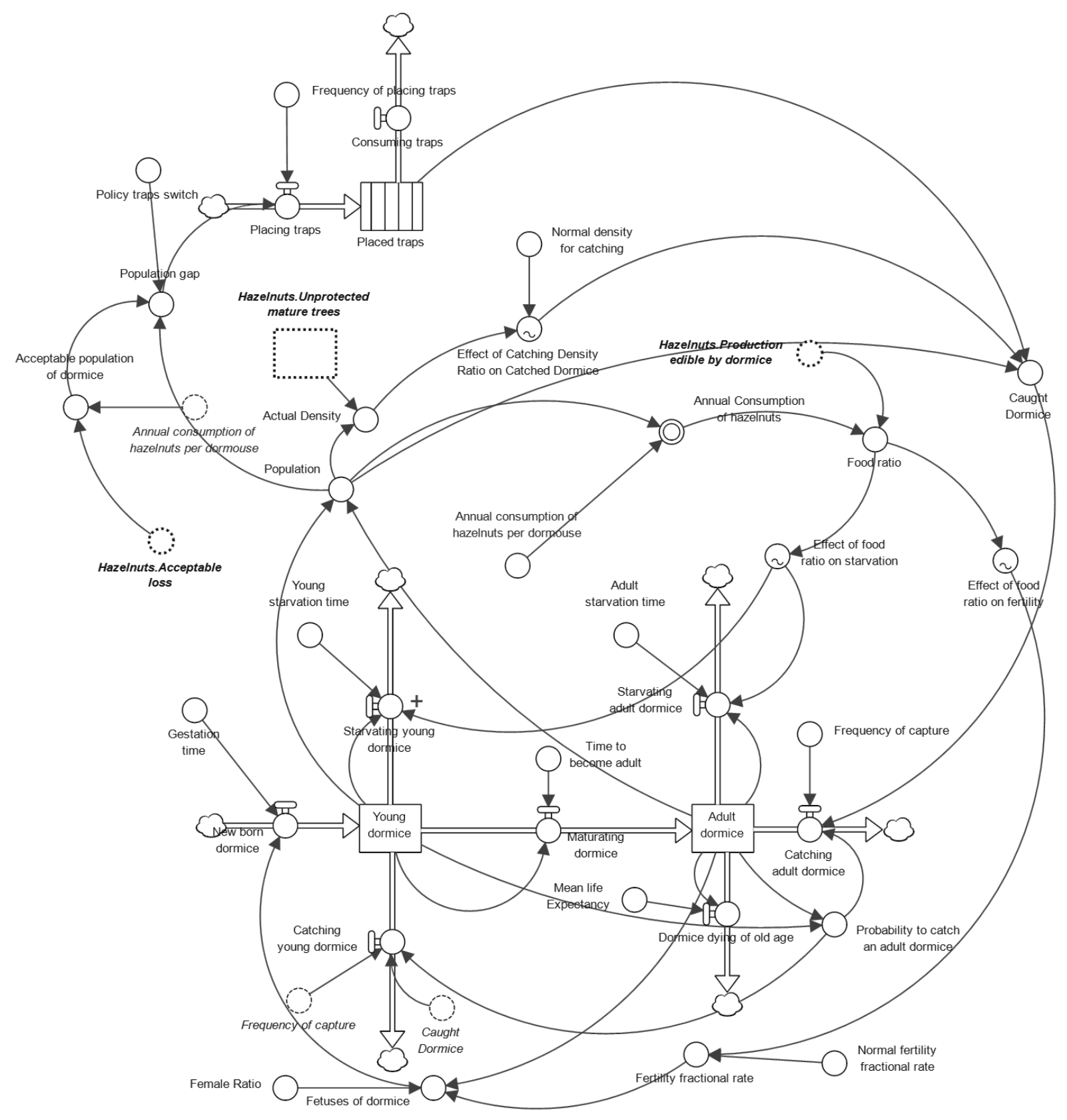


Table 2 List of Variables of the dormouse subsystem of the SFD

\begin{tabular}{|c|c|c|}
\hline Variable Name & Unit of Measure & General information and assumptions \\
\hline $\begin{array}{l}\text { Acceptable } \\
\text { population of dormice }\end{array}$ & 'Number of dormice' & $\begin{array}{l}\text { The desired population is defined by dividing the annual } \\
\text { consumption of hazelnuts per dormouse by the } \\
\text { acceptable level of hazelnut loss. }\end{array}$ \\
\hline Actual density & $\begin{array}{l}\text { 'Number of } \\
\text { dormice'/'Number of } \\
\text { trees' }\end{array}$ & $\begin{array}{l}\text { The actual density is defined as the total population of } \\
\text { dormice divided by the unprotected hazels }\end{array}$ \\
\hline Adult dormice & 'Number of dormice' & $\begin{array}{l}\text { As the initial local population of dormice is unknown, it } \\
\text { is assumed that the current population is consistent with } \\
\text { the initial equilibrium conditions }\end{array}$ \\
\hline Adult starvation time & 'Years' & $\begin{array}{l}\text { It is assumed that after } 4 \text { months of food shortages (one } \\
\text { season), the dormouse dies of malnutrition }\end{array}$ \\
\hline $\begin{array}{l}\text { Annual consumption } \\
\text { of hazelnuts per } \\
\text { dormouse }\end{array}$ & $\begin{array}{l}\text { 'Kilograms'/'Number of } \\
\text { dormice'/‘Years' }\end{array}$ & $\begin{array}{l}\text { An average annual consumption of hazelnuts of } 125 \\
\text { kilograms per year per dormouse is assumed, using a } \\
\text { study by Rodolfi (1994) as reference data }\end{array}$ \\
\hline $\begin{array}{l}\text { Catching adult } \\
\text { dormice }\end{array}$ & $\begin{array}{l}\text { 'Number of } \\
\text { dormice'/'Years', }\end{array}$ & $\begin{array}{l}\text { This value depends on the composition of the dormouse } \\
\text { population (young versus adult dormice) and on the } \\
\text { strategy of the local policy makers to place traps in the } \\
\text { area. }\end{array}$ \\
\hline $\begin{array}{l}\text { Catching young } \\
\text { dormice }\end{array}$ & $\begin{array}{l}\text { 'Number of } \\
\text { dormice'/'Years', }\end{array}$ & $\begin{array}{l}\text { As with the previous variable, this value depends on the } \\
\text { composition of the dormouse population (young versus } \\
\text { adult dormice) and on the strategy of the local policy } \\
\text { makers to place traps in the area }\end{array}$ \\
\hline Caught dormice & 'Number of dormice' & $\begin{array}{l}\text { This value depends on the number of traps and the } \\
\text { dormouse population as well on the density of the } \\
\text { dormouse population }\end{array}$ \\
\hline Consuming traps & $\begin{array}{l}\text { 'Number of } \\
\text { dormice'/'Years', }\end{array}$ & $\begin{array}{l}\text { It is assumed that every trap can contain only one } \\
\text { dormouse, therefore the model was simplified by not } \\
\text { inserting the trap variable }\end{array}$ \\
\hline $\begin{array}{l}\text { Dormice dying of old } \\
\text { age }\end{array}$ & $\begin{array}{l}\text { 'Number of } \\
\text { dormice'/'Years' }\end{array}$ & The number of dormice that are ending their life cycle \\
\hline $\begin{array}{l}\text { Effect of density ratio } \\
\text { catching on dormice } \\
\text { caught }\end{array}$ & Unitless & $\begin{array}{l}\text { Using an s-shape line in a graph function, it is assumed } \\
\text { that in the case of low dormouse density, the probability } \\
\text { of capture will decrease drastically, while there will be a } \\
\text { high probability of capture with a high density. }\end{array}$ \\
\hline $\begin{array}{l}\text { Effect of food ratio on } \\
\text { fertility }\end{array}$ & Unitless & $\begin{array}{l}\text { The model intends to portray this effect by using a graph } \\
\text { function, considering it with a horizontal asymptotic }\end{array}$ \\
\hline
\end{tabular}




\begin{tabular}{|c|c|c|}
\hline & & $\begin{array}{l}\text { pattern close to zero in the case of a lack of food and a } \\
\text { vertical asymptotic trend up to the unit value in the case } \\
\text { of a high presence of food }\end{array}$ \\
\hline $\begin{array}{l}\text { Effect of food ratio on } \\
\text { starvation }\end{array}$ & Unitless & $\begin{array}{l}\text { The model intends to portray this effect by using a graph } \\
\text { function, considering that an increase in the level of } \\
\text { starvation will cause an increase in the mortality rate less } \\
\text { than proportional to starvation. }\end{array}$ \\
\hline Female ratio & Unitless & $\begin{array}{l}\text { The model assumes a } 0.5 \text { ratio between males and } \\
\text { females }\end{array}$ \\
\hline $\begin{array}{l}\text { Fertility fractional } \\
\text { rate }\end{array}$ & $1 /$ 'Years' & $\begin{array}{l}\text { The fertility fractional rate is an endogenous variable, } \\
\text { hardly influenced by the system. This rate is influenced } \\
\text { by the availability of food (LEBL et al., 2010). }\end{array}$ \\
\hline Foetuses of dormice & $\begin{array}{l}\text { 'Number of } \\
\text { dormice'/'Years', }\end{array}$ & Number of new dormice that are about to be born \\
\hline Food ratio & Unitless & $\begin{array}{l}\text { This is a ratio between the available supply of hazelnuts } \\
\text { and the demand for hazelnuts by the dormice }\end{array}$ \\
\hline Frequency of capture & 1/'Years' & It is assumed a single frequency per year \\
\hline $\begin{array}{l}\text { Frequency of trap } \\
\text { placement }\end{array}$ & $1 /$ 'Years' & A single instance per year is assumed \\
\hline Population gap & 'Number of dormice' & $\begin{array}{l}\text { This value defines the efforts of the farmers to place } \\
\text { traps. The higher the gap between the acceptable } \\
\text { population and the current population of dormice, the } \\
\text { higher the number of traps placed will be. }\end{array}$ \\
\hline Gestation time & 'Years' & $\begin{array}{l}\text { An average gestation time of one month is assumed, as } \\
\text { stated by Kryštufek (2010). }\end{array}$ \\
\hline Hazelnuts.desired loss & 'Kilograms'/'Years' & This variable was imported from the hazelnut subsystem \\
\hline $\begin{array}{l}\text { Hazelnuts.production } \\
\text { eatable by dormice }\end{array}$ & 'Kilograms'/'Years' & This variable was imported from the hazelnut subsystem \\
\hline $\begin{array}{l}\text { Hazelnuts.unprotected } \\
\text { mature trees }\end{array}$ & 'Number of trees' & This variable was imported from the hazelnut subsystem \\
\hline Maturating dormice & $\begin{array}{l}\text { 'Number of } \\
\text { dormice'/'Years' }\end{array}$ & The number of dormice that are becoming adults \\
\hline $\begin{array}{l}\text { Maximum fertility } \\
\text { fractional rate }\end{array}$ & $1 /$ 'Years' & $\begin{array}{l}\text { The maximum fertility fractional rate was defined as } 11 \text {, } \\
\text { as stated by Kryštufek (2010). }\end{array}$ \\
\hline Mean life expectancy & 'Years' & $\begin{array}{l}\text { As a new-born dormouse takes one year to become adult, } \\
\text { it is assumed that its mean life expectancy should be } 5 \\
\text { years. }\end{array}$ \\
\hline New-born dormice & $\begin{array}{l}\text { 'Number of } \\
\text { dormice'/'Years' }\end{array}$ & This variable is defined by a delay function of first order. \\
\hline
\end{tabular}




\begin{tabular}{|c|c|c|}
\hline $\begin{array}{l}\text { Normal density for } \\
\text { catching }\end{array}$ & $\begin{array}{l}\text { 'Number of } \\
\text { dormice'/'Number of } \\
\text { trees' }\end{array}$ & $\begin{array}{l}\text { This is a parameter that defines the normal level of } \\
\text { population density; the capture rate of dormice will be } \\
\text { affected if the density is lower than this value }\end{array}$ \\
\hline Traps placed & 'Number of dormice' & $\begin{array}{l}\text { The number of traps placed. It is assumed that every trap } \\
\text { can contain only one dormouse, therefore, the model was } \\
\text { simplified by not inserting the 'trap' unit of measure. }\end{array}$ \\
\hline Placing traps & $\begin{array}{l}\text { 'Number of } \\
\text { dormice'/'Years' }\end{array}$ & $\begin{array}{l}\text { Due to the delay of accumulation, the model considers } \\
\text { the variable Placing traps as a step function starting in } \\
2010 .\end{array}$ \\
\hline Policy traps switch & $\begin{array}{l}\text { Dummy value }(0,1) \text {. } \\
\text { Unitless }\end{array}$ & $\begin{array}{l}\text { This is a policy lever to start the process of protecting } \\
\text { trees. }\end{array}$ \\
\hline Population & 'Number of dormice' & $\begin{array}{l}\text { The total population is computed as the sum of young } \\
\text { dormice and adult dormice. }\end{array}$ \\
\hline $\begin{array}{l}\text { Probability of } \\
\text { catching an adult } \\
\text { dormouse }\end{array}$ & Unitless & $\begin{array}{l}\text { This value depends on the composition of the dormouse } \\
\text { population (young and adult dormice). It is computed as } \\
\text { follows: 'adult dormice / (young dormice + adult } \\
\text { dormice)' }\end{array}$ \\
\hline $\begin{array}{l}\text { Starving adult } \\
\text { dormice }\end{array}$ & $\begin{array}{l}\text { 'Number of } \\
\text { dormice'/'Years', }\end{array}$ & $\begin{array}{l}\text { This value defines the annual number of adult dormice } \\
\text { that are starving }\end{array}$ \\
\hline $\begin{array}{l}\text { Starving young } \\
\text { dormice }\end{array}$ & $\begin{array}{l}\text { 'Number of } \\
\text { dormice'/'Years', }\end{array}$ & $\begin{array}{l}\text { This value defines the annual number of young dormice } \\
\text { that are starving }\end{array}$ \\
\hline Time to become adult & 'Years' & $\begin{array}{l}\text { It is assumed that a new-born dormouse spends an } \\
\text { average of one year becoming an adult }\end{array}$ \\
\hline Young dormice & 'Number of dormice' & $\begin{array}{l}\text { As the initial local population of dormice is unknown, a } \\
\text { dormouse population consistent with the initial } \\
\text { equilibrium conditions is assumed }\end{array}$ \\
\hline Young starvation time & 'Years' & $\begin{array}{l}\text { It is assumed to be the same value as the adult starvation } \\
\text { time }\end{array}$ \\
\hline
\end{tabular}

The model is consistent with the conclusions of Ghirardi et al. (2010), showing that some features of the Hazels (proximity to the forest and interweaving of the branches of the hazels) are statistically correlated with the density of dormice, detected in cultivated fields. The two subsystems are strictly linked. An increase in hazelnuts will increase the dormouse population until reaching a stable ratio. An increase in dormice will decrease the effective production, causing a reduction in the dormouse population for lack of food. Therefore, this ecosystem will be stable unless the farmers introduce a shock to the environment. 


\section{Results and Discussion}

The initial values and parameters were estimated from the primary and secondary data collected from research reports, especially from ISPRA (2015 and 2016); in case of the absence of quantitative data, some assumptions have been made, consistent with the qualitative information. The main assumptions are based on the value of some inputs.

The model shows three policies implemented: planting new trees to satisfy the market demand, protecting trees from dormice and placing traps to catch dormice.

In synthesis, the model shows different scenarios. Figure 5 shows the comparison between the historical data (dashed lines) and the simulation data (dotted lines), using both implemented policies.

Figure 5 Simulated and historical data of hazelnut production in the Province of Cuneo
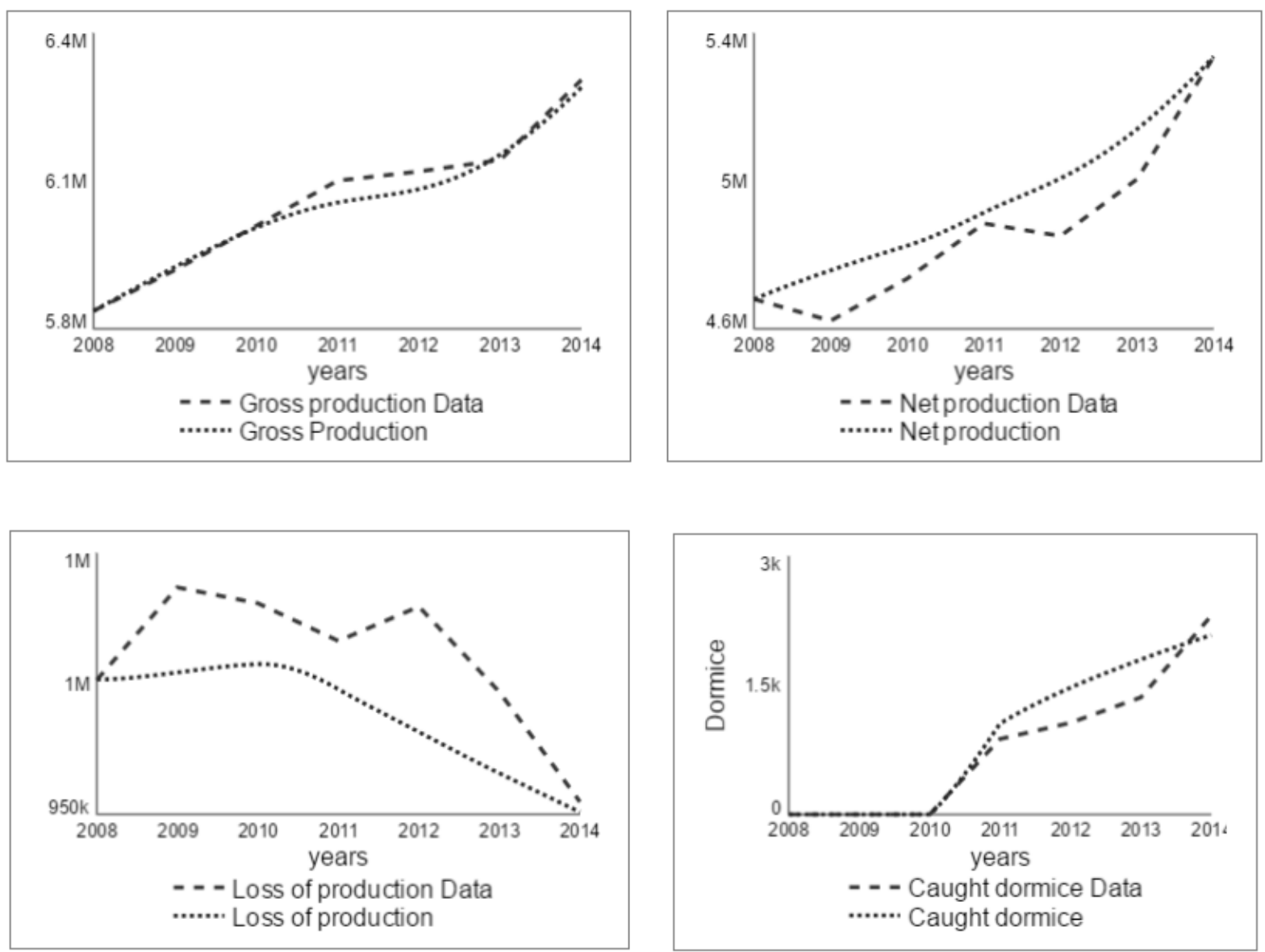

Source: ISPRA (2015)

Running the simulation, it is possible to change the set of the implemented policies. Applying all strategies (Fig. 6 ), the farmers have the lowest loss of production; while through the implementation of only one strategy, the loss of production behaves differently. Adopting the strategy protecting trees, the loss continues to decrease to seek the goal of acceptable loss, because the dormouse population will decrease because of starvation. The model agrees with a recent study by Cimini et al. (2016) that suggests that there is no single preventive method that can eliminate 
the damage caused by the dormouse; however, the concomitant use of other management actions may be able to reduce the damage suffered. Cimini et al.'s study was carried out through the monitoring of sample plots.

Figure 6 Applying different sets of policies
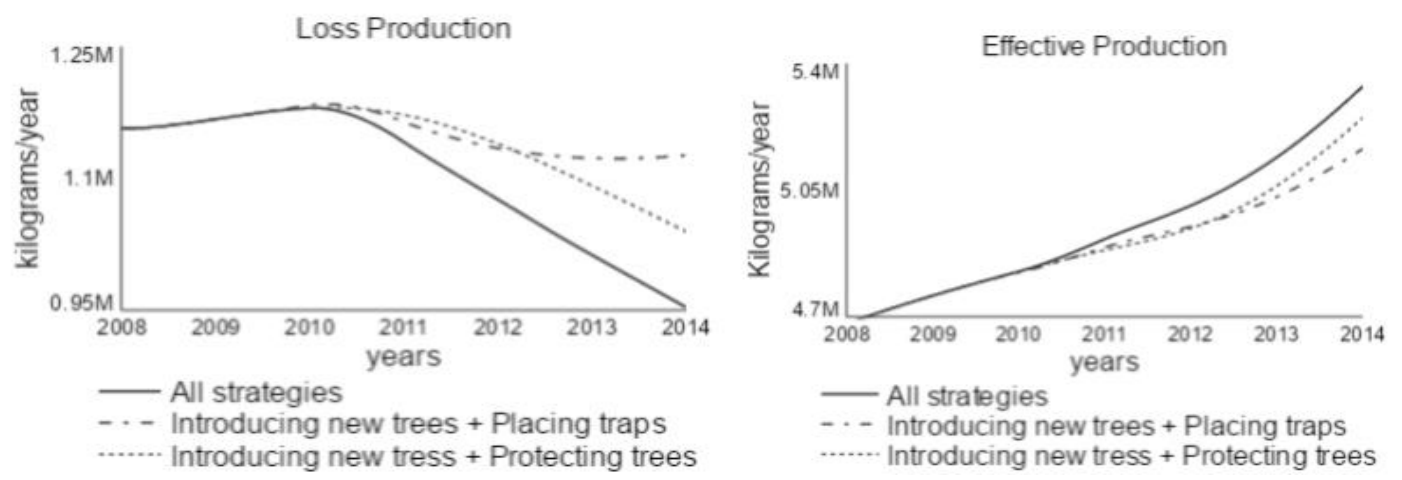

Source: Own elaboration

The initial CLD (Fig. 2) helps to understand the dynamics of the policies implemented. An increase in dormice caught will decrease the dormice population, but these efforts to reduce the loss gap will suffer a sort of attrition due to balancing loops 1, 2 and 3. Moreover, in the long run, the policy makers will need more financial resources to place more traps because of the presence of a reinforcing loop. An increase in traps placed will decrease the food competition among dormice, causing an increase in its population, a reduction in the starvation rate and an increase in fertility rate due to the abundance of food, and, therefore, a consequent increase in traps to be placed. The policy protecting trees will reduce the dormice population exponentially, because of the dominating presence of the balancing loops. This policy should consider that a reduction in available trees will be effective to limit the reproductive capacity only if this reduction reaches a certain threshold (Fietz et al., 2005). Concerning the relevance of ecotonal orchard-forest zones, Capizzi and Santini (2007) state that branches providing contact between hazels and trees in wild wooded areas represent preferential transition points for dormice during the night invasions of orchards.

Because of the organizational and temporal complexity of ecosystems, human intervention may have different effects at different times; these effects may also depend on which ecosystem components are impacted. More complex institutions may be necessary to maintain ecosystem functions in the face of human use, and they may govern not just the level and intensity but the timing, spatial pattern, and specific form of resource use. In principle, there is an inherent unawareness, as well as unpredictability, concerning these evolving managed ecosystems and the societies with which they are linked. The essential point is that evolving systems require policies and actions that not only satisfy social objectives but also achieve a continually modified understanding of the evolving conditions and provide flexibility for adaptation to surprises (Folke et al., 2007).

\section{Conclusions}

The predator-prey model shows that hazelnut production is affected by the presence of dormice. Using this SD model, it is possible to explain the operational relationships between the variables. The impact of several balancing loops shows that the presence of this animal is so endemic in the territory that only by changing the distinctive 
characteristics of the local area (for example, by protecting all the trees) is it possible to find a sustainable solution in terms of hazelnut production. This implies several costs for the communities involved, and, because of the boundaries of the model, it is not clear if a drastic reduction can cause other effects on the ecosystem.

The study finds that a mixed strategy could improve hazelnut production, but without protecting hazel groves (e.g., with safety nets, ultrasound, pruning, etc.), no policy will be fully sustainable.

Although this study illuminates the effects of two macro-strategies (trapping and protecting trees), a deeper study should be considered to analyse the dynamic effectiveness of different micro-strategies for protecting trees, such as a buffer zone around hazel orchards (no-tree zones), physical barriers and chemical deterrents, which differ in cost, arrangement time and maintenance (Ghirardi et al, 2011).

Further, this model can be a starting point to establish an interactive learning platform for local policy makers to employ in implementing similar policies and developing engagement among the stakeholders to build understanding of the dynamic complexity of this issue. Indeed, as the implementation of successful policies requires the involvement of different stakeholders and uncertainties are likely to remain high, this work could represent a tool for developing a facilitation strategy in which stakeholders elaborate shared ambitions and directions for solutions, and ecological scientists extend their participation in scientifically assessing policy alternatives (Hanssenn et al., 2009).

\section{ACKNOWLEDGEMENT}

The author would like to thank David Wheat (University of Bergen), Eduard Romanenko (University of Bergen), Andrea Cuccia (Università degli Studi di Palermo), Inge Bleijenbergh (Radboud University), Mariano Sereno (Province of Cuneo) and Valentina La Morgia (ISPRA). 


\section{REFERENCES}

Bianchi C. (2016). Dynamic Performance Management. 1st ed. Springer International Publishing Switzerland, Cham, Switzerland.

Capizzi D., Santini L. (2007). I Roditori italiani. Ecologia, impatto sulle attività umane e sugli ecosistemi, gestione delle popolazioni. Antonio Delfino Editore, Rome, Italy.

Chan S. L., S. L. Huang (2004). 'A systems approach for the development of a sustainable community — the application of the sensitivity model (SM).' Journal of Environmental Management. Vol. 72, pp. 133-147.

Cimini M., et al. (2016). 'Il ghiro e le colture di nocciolo: problematiche, impatto e prime sperimentazioni di metodi di prevenzione del danno.' Paper presented at the III Congresso Nazionale Fauna Problematica, November 2016. Cesena, FC, Italy.

Ekins P., Folke C., De Groot R. (2003) 'Identifying Critical Natural Capital.' Ecological Economics Vol 44. Issue. 2-3, pp. 159-163.

Fietz J., Pflug M., Schlund W., Tataruch F. (2005). 'Influences of the feeding ecology on body mass and possible implications for reproduction in the edible dormouse (Glis glis).' Journal of Comparative Physiology Biochemical, Systems, and Environmental Physiology: Vol. 175, Issue 1, pp. 45-55.

Folke, C., Pritchard L., Berkes F., Colding J., Svedin U. (2007). 'The problem of fit between ecosystems and institutions: ten years later.' Ecology and Society. Vol. 12. Issue 1. [Online] http://www.ecologyandsociety.org/vol12/iss1/art30/ (accessed on 29 June 2018).

Ford A. (2009). Modeling the environment (2nd ed.), Island Press, Washington, DC, USA.

Forrester, J. W. (1969) Urban dynamics, M.I.T. Press, Cambridge, MA, USA.

Ghirardi M., Tizzani P., Dematteis A. (2010). 'Valutazione preliminare dell'impatto del ghiro Glis glis sulle colture di nocciolo nei territori dell'Alta Langa e Valle Belbo, Bormida e Uzzone (Cuneo): considerazioni sui sistemi incruenti di prevenzione del danno.' Paper presented at the Convegno Italiano sui piccoli mammiferi "Ricerca, Gestione e Conservazione dei Piccoli Mammiferi”, February 2010, Riserva Naturale Regionale Nazzano, Agenzia Regionale Parchi, Tevere - Farfa, Italy.

Ghirardi M., Tizzani P., Dematteis A. (2011). 'Impact of the fat dormouse (Glis glis Linnaeus 1766) on hazel orchards in the area of Alta Langa and Belbo, Bormida, Uzzone Valleys (Province of Cuneo, Italy): a preliminary assessment of agricultural damage.' Paper presented at the 8th European Vertebrate Pest Management Conference. Berlin, Germany, September 2011.

Ghosh A. (2017), Dynamic Systems for Everyone: Understanding How Our World Works. $2^{\text {nd }}$ ed. Springer International Publishing Switzerland, Cham, Switzerland.

Hanssen, L., E. Rouwette, and M. M. van Katwijk. (2009). 'The role of ecological science in environmental policy making: from a pacification toward a facilitation strategy.' Ecology and Society. Vol. 14. Issue 1. [online] URL: http://www.ecologyandsociety.org/vol14/iss1/art43/ (accessed on 29 June 2018).

ISPRA - Istituto Superiore per la Protezione e la Ricerca Ambientale (2015). Report 2014. Limiting the damage caused by dormice to the cultivation of hazelnuts. Province of Cuneo. Cuneo. Italy

ISPRA - Istituto Superiore per la Protezione e la Ricerca Ambientale (2016). Report 2015. Limiting the damage caused by dormice to the cultivation of hazelnuts. Province of Cuneo. Cuneo. Italy 
Juškaitis R., Baltrūnaitė L., Augutė V. (2015). 'Diet of the fat dormouse (Glis glis) on the northern periphery of its distributional range.' Mammal Research. Vol. 60 No.2, pp.155 - 161

Kryštufek B. (2010). 'Glis glis (Rodentia: Gliridae).' Mammalian Species - American Society of Mammologists: Vol. 42, No. 865, pp. 195-206.

Lebl K., Kürbisch K., Bieber C., Ruf T. (2010). 'Energy or information? The role of seed availability for reproductive decisions in edible dormice.' Journal of Comparative Physiology Biochemical, Systems, and Environmental Physiology Vol. 180, pp. 447-456.

Levin S. A. (1992). 'The problem of pattern and scale in ecology.' Ecology. Vol. 73, pp. 1943-1967.

Martin, L., et al. (2007). 'Microworld gaming of a local agricultural production chain in Poland.' Simulation \& Gaming: Vol. 38. No. 2, pp. 211-232.

Morecroft J. (1998). 'Resource System Management and Dynamic Complexity.' Paper Presented at the 4th International Conference on Competence-based Management. June 1998. Oslo, Norway.

Odum E. P. (1989). Ecology and our endangered life-support systems. Sinauer Associates. Sunderland, MA, USA.

Pretty J. (2007). The Earth Only Endures: On Reconnecting with Nature and Our Place in It. Earthscan, James and James (Science Publishers), London, UK.

Rodolfi G. (1994), 'Dormice Glis glis activity and hazelnuts consumption', Acta Theriologica Vol. 39. No. 2, pp. 215-220.

Senge P. (1990). The fifth discipline. Doubleday. New York, NY, USA.

Škraba A. (2008). 'Strategy for organic farming model development.' Paper presented at the Conference: 26th International System Dynamics Society Conference. July 2008. Athens, Greece.

Sonak, S. M. (2013). Khazan Ecosystems of Goa. 1st ed. Springer, Dordrecht, The Netherlands

Sterman, J. (2000). Business dynamics. Systems Thinking and modeling for a complex world. Irwin/McGraw Hill, Boston, USA.

Sterman, J. (1994). 'Learning In and About Complex Systems.' Working paper (Sloan School of Management). 3660-94. [online] URL: http://hdl.handle.net/1721.1/2504 (accessed on 29 June 2018).

Thompson, J., Millstone E., Scoones I. (2007). 'Agrifood system dynamics: Pathways to sustainability in an era of uncertainty.' STEPS working paper 4. Brighton: STEPS Centre. Institute of Development Studies, University of Sussex, Brighton, UK.

Wangersky P. J. (1978), 'Lotka-Volterra Population Model's, Annual Review of Ecology and Systematics Vol. 9 No. 1, pp. 189-218.

Worster D. (1994). The wealth of nature: environmental history and the ecological imagination. Oxford University Press; New York, NY, USA. 